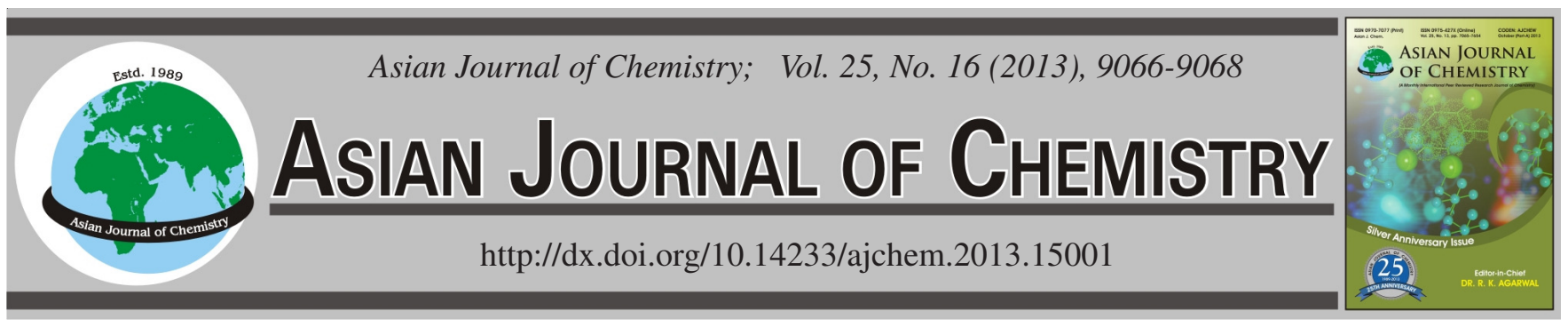

\title{
Synthesis of 2-(Phenylcarbamoyl)phenyl Acetate and Its Antifungal Activity
}

\section{YuQI CHEN ${ }^{1, *}$ and HuI FenG ${ }^{2}$}

${ }^{1}$ Institute of Light Industry and Food Engineering, Guangxi University, Nanning 530004, P.R. China

${ }^{2}$ School of Bioengineering, Xihua University, Chengdu 610039, P.R. China

*Corresponding author: Tel: +86 28 87720763; E-mail: shengxiaohongb@qq.com

(Received: 20 December 2012;

Accepted: 16 September 2013)

AJC-14114

2-(Phenylcarbamoyl)phenyl acetate was synthesized by the ammonolysis of 2-(chlorocarbonyl)phenyl acetate. Its structure was confirmed by IR and ${ }^{1} \mathrm{H}$ NMR. Its antifungal activity against Rhizoctonia solani and Helminthosprium maydis has been studied. It had good antifungal activity against the above two different pathogenic fungi of plants. Its median effective concentrations $\left(\mathrm{EC}_{50}\right)$ were 22.9 and $6.8 \mathrm{mg} \mathrm{L}^{-1}$, respectively.

Key Words: Antifungal activity, 2-(Phenylcarbamoyl)phenyl acetate, Synthesis.

\section{INTRODUCTION}

Rhizoctonia solani is a harmful disease of paddy rice ${ }^{1}$. For a long period, benzimidazole fungicides have been mostly used to control it. However, it has developed resistance to the above fungicides ${ }^{2-6}$. Moreover, its scope of resistance continues to expand and has already included many new fungicides ${ }^{7-9}$.

Similarly, Helminthosprium maydis is a pathogenic fungus of plants which has serious harm to maize. Over the past decades, synthetic fungicides including carbendazim have been used to prevent it. Nevertheless, the development of its resistance to all the fungicides has reduced the efficacy of fungicidal treatment ${ }^{10-16}$. Therefore, new fungicides are continually required.

It is well-known that since aspirin (acetylsalicylic acid) was first marketed in 1899, it has been widely used for the treatment of pains, fever and colds ${ }^{17-29}$. Thus, in present report, 2-(phenylcarbamoyl)phenyl acetate was synthesized based on aspirin. Its antifungal activity has been evaluated to find new fungicides with high efficacy and low toxicity.

\section{EXPERIMENTAL}

Rhizoctonia solani and Helminthosprium maydis were obtained from the Chinese Academy of Agricultural Sciences. They were preserved at $4{ }^{\circ} \mathrm{C}$. All chemicals and solvents were purchased from commercial sources unless specified otherwise. IR spectra were recorded on a Thermofisher Nicolet-6700 spectrophotometer. ${ }^{1} \mathrm{H}$ NMR spectra were taken on a Varian Unity Inova-400 instrument using deuteron-chloroform as the solvent.
Synthesis of target compound: The target compound was synthesized according to the reaction shown in Fig. 1. Aniline $(0.02 \mathrm{~mol})$ and pyridine $(0.02 \mathrm{~mol})$ were dissolved in $\mathrm{CH}_{2} \mathrm{Cl}_{2}(15 \mathrm{~mL})$. The mixture was stirred and heated to $35-$ $45^{\circ} \mathrm{C}$. 2-(Chlorocarbonyl)phenyl acetate $(0.02 \mathrm{~mol})$ with $\mathrm{CH}_{2} \mathrm{Cl}_{2}(15 \mathrm{~mL})$ was slowly added to the above mixture under stirring until the reaction was complete. The precipitate was filtered and washed with stilled water. The pure compound was obtained by re-crystallization in anhydrous ethanol.

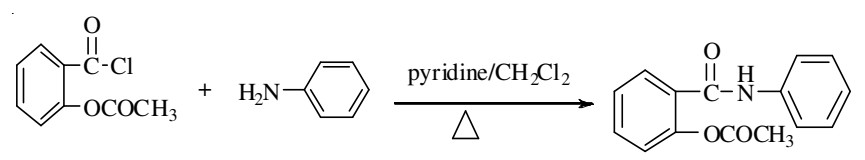

Fig. 1. Synthetic method of 2-(phenylcarbamoyl) phenyl acetate

Synthesized compound $\left(\mathrm{C}_{15} \mathrm{H}_{13} \mathrm{O}_{3} \mathrm{~N}\right)$ : light yellow powder; yield: $75.0 \%$; m.p. $152-153{ }^{\circ} \mathrm{C}$; IR( $\left.\mathrm{KBr}, \mathrm{v}_{\max }, \mathrm{cm}^{-1}\right)$ : 3243, 3191, 3131, 3072, 3040, 1760, 1649, 1597, 1542, 1494, 1451, 1370, 1327, 1300, 1195, 1156, 1097, 758, 748, 709, 596; ${ }^{1} \mathrm{H}$ NMR $\left(400 \mathrm{MHz}, \mathrm{CDCl}_{3}\right) \delta(\mathrm{ppm}): 8.08(\mathrm{~s}, 1 \mathrm{H}), 7.83$ $(\mathrm{d}, J=7.6 \mathrm{~Hz}, 1 \mathrm{H}), 7.60(\mathrm{~d}, J=8.0 \mathrm{~Hz}, 2 \mathrm{H}), 7.49-7.53(\mathrm{~m}$, 1H), 7.33-7.38 (m, 3H), 7.13-7.17 (m, 2H), 2.32 (s, 3H).

Assay of antifungal activity: The antifungal activity of the synthesized compound against Rhizoctonia solani and Helminthosprium maydis was determined using the plate growth rate method ${ }^{30}$.

The synthesized compound and carbendazim (purity $90 \%$ ) were dissolved in dimethyl sulfoxide, respectively. The two solutions were diluted into five different concentrations 
with distilled water, respectively. They were added to the sterile culture medium (PDA) at $45^{\circ} \mathrm{C}$, mixed to homogeneity and transferred to sterile Petri dishes to solidify. A mycelium agar disc ( $5 \mathrm{~mm}$ in diameter) of the target fungi was placed in the center of PDA plates. They were incubated at $28^{\circ} \mathrm{C}$ in the dark until the target fungi used as controls covered the surface of these plates. Control groups were treated with the corresponding solutions without the synthesized compound or carbendazim. The experiment for each concentration was replicated three times. The diameter of the fungi in the cultures was measured and the inhibition of growth was calculated according to the formula of Abbott. $\mathrm{EC}_{50}$ values were calculated with the Statistics Package for the Social Sciences (SPSS) based on probit analysis.

\section{RESULTS AND DISCUSSION}

Antifungal activity against Rhizoctonia solani: Compared with the efficient fungicide carbendazim, the synthesized compound was submitted to laboratorial bioassay. The results are presented in Table-1. It had good antifungal activity against Rhizoctonia solani. Its $\mathrm{EC}_{50}$ value was $22.9 \mathrm{mg} \mathrm{L}^{-1}$. The results of regressive and correlative analyses indicated that the correlation was significant between concentration and efficacy. Its correlative coefficient was 0.9635 . Chi-square test demonstrated that the results were reliable $\left(\chi^{2}=2.913, \mathrm{df}=3, p>\right.$ 0.05).

Antifungal activity against Helminthosprium maydis: As shown in Table-2, using the efficient fungicide carbendazim as the comparative standard, the synthesized compound was subjected to laboratorial bioassay. Its $\mathrm{EC}_{50}$ value reached 6.8 $\mathrm{mg} \mathrm{L}^{-1}$. The results of regressive and correlative analyses revealed that the correlation was significant between concentration and efficacy. The correlative coefficient was 0.9776 . As for the results of Rhizoctonia solani, chi-square test also showed that the results were reliable $\left(\chi^{2}=4.241, \mathrm{df}=3, p>\right.$ $0.05)$.
The target compound 2-(phenylcarbamoyl) phenyl acetate has been successfully synthesized by means of the ammonolysis of 2-(chlorocarbonyl) phenyl acetate and then its structure has been confirmed with the aid of IR and ${ }^{1} \mathrm{H}$ NMR.

The results of laboratory bioassay have apparently shown that though the antifungal activity of 2-(phenylcarbamoyl) phenyl acetate against Rhizoctonia solani was inferior to carbendazim, its antifungal activity against Helminthosprium maydis was superior to carbendazim. Therefore, the structural modification of aspirin was very successful. In addition, the structure of the obtained compound is simple and its chemical synthesis is easy. Thus, based on it, more derivatives may be further synthesized so as to survey quantitative structureactivity relationships and find new fungicides with high efficacy and low toxicity as well as safety to non-target organisms. On the other hand, the compound is also promising in the agricultural chemistry field because it had good antifungal activity against the two different pathogenic fungi of plants.

However, in order to realize the industrialization of the compound as a fungicide, more research work needs doing. Its antifungal spectrum needs to be determined. Its mode of action and its safety to humans and non-target organisms also need to be further investigated.

\section{ACKNOWLEDGEMENTS}

This project was supported by the Science and Technology Support Program of Sichuan Province (2009PZ0055).

\section{REFERENCES}

1. X.J. Chen, M.J. Cao, Y. Wang, Y.H. Tong and J.Y. Xu, Chin. J. Oil Crop Sci., 31, 503 (2009).

2. Y.L. Pan, Z.Y. Wang and H.Z. Wu, J. Jiangsu Agric., 13, 32 (1997).

3. Z.Q. Shi, M.G. Zhou and Z.Y. Ye, J. Jiangsu Agric., 16, 212 (2000).

4. W. Li, W. Li, Y.-J. Zhou and H.G. Chen, Chin. J. Oil Crop Sci., 29, 63 (2007).

5. K.Y. Liu and F.X. Chen, Anhui Agric. Sci., 35, 756 (2007).

6. R.E. Beever and H.M.R. Brien, Agric. Res., 26, 391 (1983).

TABLE-1

ANTIFUNGAL ACTIVITY OF 2-(PHENYLCARBAMOYL) PHENYL ACETATE AGAINST Rhizoctonia solani

\begin{tabular}{|c|c|c|c|c|c|c|c|c|c|c|}
\hline & \multicolumn{5}{|c|}{ 2-(Phenylcarbamoyl)phenyl acetate } & \multicolumn{5}{|c|}{ Carbendazim } \\
\hline Concentration $\left(\mathrm{mg} \mathrm{L}^{-1}\right)$ & 100 & 50 & 25 & 12.5 & 6.3 & 12.5 & 6.3 & 3.1 & 1.6 & 0.8 \\
\hline Inhibition of growth* (\%) & 88.7 & 73.3 & 48.4 & 28.7 & 20.5 & 96.5 & 91.7 & 73.4 & 59.8 & 52.4 \\
\hline Regressive equation $(\mathrm{Y}=\mathrm{aX}+\mathrm{b})$ & \multicolumn{5}{|c|}{$Y=1.7449 X+2.6267$} & \multicolumn{5}{|c|}{$\mathrm{Y}=1.4684 \mathrm{X}+5.0660$} \\
\hline $\mathrm{EC}_{50}\left(\mathrm{mg} \mathrm{L}^{-1}\right)$ & \multirow{2}{*}{\multicolumn{5}{|c|}{22.9}} & \multicolumn{5}{|c|}{0.9} \\
\hline$(95 \% \mathrm{Cl})$ & & & & & & \multicolumn{5}{|c|}{$(0.6-1.2)$} \\
\hline Correlative coefficient (r) & \multicolumn{5}{|c|}{0.9635} & \multicolumn{5}{|c|}{0.9585} \\
\hline$\chi^{2}$ & \multicolumn{5}{|c|}{2.913} & \multicolumn{5}{|c|}{4.508} \\
\hline
\end{tabular}

TABLE-2

ANTIFUNGAL ACTIVITY OF 2-(PHENYLCARBAMOYL) PHENYL ACETATE AGAINST Helminthosprium maydis

\begin{tabular}{|c|c|c|c|c|c|c|c|c|c|c|}
\hline \multirow[b]{2}{*}{ Concentration $\left(\mathrm{mg} \mathrm{L}^{-1}\right)$} & \multicolumn{5}{|c|}{ 2-(Phenylcarbamoyl)phenyl acetate } & \multicolumn{5}{|c|}{ Carbendazim } \\
\hline & 100 & 50 & 25 & 12.5 & 6.3 & 100 & 50 & 25 & 12.5 & 6.3 \\
\hline Inhibition of growth* $(\%)$ & 92.5 & 84.1 & 68.0 & 57.2 & 54.2 & 87.5 & 70.8 & 57.5 & 41.5 & 35.5 \\
\hline Regressive equation $(\mathrm{Y}=\mathrm{aX}+\mathrm{b})$ & \multicolumn{5}{|c|}{$Y=1.1037 X+4.0798$} & \multicolumn{5}{|c|}{$Y=1.2373 X+3.5189$} \\
\hline $\mathrm{EC}_{50}\left(\mathrm{mg} \mathrm{L}^{-1}\right)$ & \multicolumn{5}{|c|}{6.8} & \multicolumn{5}{|c|}{15.7} \\
\hline$(95 \% \mathrm{Cl})$ & \multicolumn{5}{|c|}{$(4.1-9.5)$} & \multicolumn{5}{|c|}{$(12.1-19.6)$} \\
\hline Correlative coefficient (r) & \multicolumn{5}{|c|}{0.9776} & \multicolumn{5}{|c|}{0.9808} \\
\hline$\chi^{2}$ & \multicolumn{5}{|c|}{4.241} & \multicolumn{5}{|c|}{2.862} \\
\hline
\end{tabular}

*Based on the mean of triplicates. 
7. D.G. Hutton, Australasian Plant Pathol., 17, 34 (1988).

8. Y.X. Qi, F.X. Chen and K.J. Ding, Pesticides, 8, 567 (2006).

9. FAO, FAO Plant Protect. Bull., 30, 30 (1982).

10. A. Have, R. Van Berloo, P. Lindhout and J.A.L. Van Kan, Eur. J. Plant Pathol., 113, 153 (2007).

11. S.I. Ignatova, N.S. Gorshkova and T.A. Tereshonkova, Acta Physiol. Plant, 22, 326 (2000).

12. H. Egashira, A. Kuwashima, H. Ishiguro, K. Fukushima, T. Kaya and S. Imanishi, Acta Physiol. Plant, 22, 324 (2000).

13. R.L. Guimaraes, R.T. Chetelat and H.U. Stotz, Eur. J. Plant Pathol., 110, 13 (2004).

14. R. Finkers, P. van de Berg, R. van Berloo, A. Have, A.W. van Heusden, J.A.L. van Kan and P. Lindhout, Theor. Appl. Genet., 114, 585 (2007)

15. Richard Finkers, A.W. van Heusden, F. Meijer-Dekens, J.A.L. van Kan, P. Maris and P. Lindhout, Theor. Appl. Genet., 114, 1071 (2007).

16. R. Finkers, Y.L. Bai, P. van de Berg, R. van Berloo, A. Have, J.A.L. van Kan, P. Lindhout and A.W. van Heusden, Euphytica, 159, 83 (2008).

17. X. Wang, Med. Hypotheses, 50, 239 (1998).
18. D.W. Gilroy, Prostag. Leukotr. Ess., 73, 203 (2005).

19. C. Millikan and N. Futrell, J. Stroke Cerebrovasc Dis., 5, 248 (1995).

20. J.R. Vane, R.J. Flower and R.M. Botting, Stroke, 21, 12 (1990).

21. M.L. Dyken, H.J.M. Barnett, J.D. Easton, W.S. Fields, V. Fuster, V. Hachinski, J.W. Norris and D.G. Sherman, Stroke, 23, 1395 (1992).

22. H. Tohgi, S. Konno, K. Tamura, B. Kimura and K. Kawano, Stroke, 23, 1400 (1992).

23. R.H. Ackerman and K.L. Newman, Ann. Neurol., 28, 224 (1990).

24. C.M. Helgason, K.L. Tortorice, S.R. Winkler, D.W. Penney, J.J. Schuler, T.J. McClelland and L.D. Brace, Stroke, 24, 345 (1993)

25. W.K. Hass, J.D. Easton, H.P. Adams Jr, W. Pryse-Phillips, B.A. Molony, S. Anderson and B. Kamm, N. Engl. J. Med., 321, 501 (1989).

26. D.M. McCarthy, Best Pract. Res. Clin. Gastroenterol., 26, 101 (2012).

27. R. Eccles, Int. Pharm. J., 6, 7 (1995).

28. C. Lampl, M. Voelker and H.C. Diener, J. Neurol., 254, 705 (2007).

29. J.A. Forbes, I.A. Edquist, F.G. Smith, M.K. Schwartz and W.T. Beaver, Pharmacotherapy, 11, 64 (1991).

30. W. Huang and G.F. Yang, Bioorg. Med. Chem., 14, 8280 (2006). 